\title{
Preliminary Study on the Role of Creativity in Outdoor Recreation Activities towards Enhancing Visitors' Experience in Malaysia
}

\author{
Siti Suriawati Isa and Azlizam Aziz
}

\begin{abstract}
Tourism destinations should not depend too much on their natural resources alone nowadays. They should manage their natural resources creatively without compromising with the environment. Creativity and innovation are becoming key elements to attract visitors to a destination in this era. The main concern of this research is to examine creativity and innovation elements used by Malaysian outdoor recreation stakeholders and market players for their activities. Mixed methods were applied to get an in depth understanding about $\mathrm{th}$ is novel topic. Secondary data taken from related literature on this topic were presented for this preliminary study stage. The results of the initial phase of the study indicate that the outdoor recreation development in Kedah is significantly limited, while in Pahang there are areas for improvement and in Selangor future development need more creative approaches. In general creativity is still lacking relating to the activities and marketing aspects in outdoor recreation.
\end{abstract}

Index Terms-Creativity, Malaysia, outdoor recreation, visitors' experience.

\section{INTRODUCTION}

Outdoor recreation has become an important agenda for tourists when they visit tourism destinations. It is also an important leisure activity for local community nowadays. In addition the awareness of the general public on the good impact of outdoor recreation to a healthy lifestyle has caused significant increases in the demand of outdoor recreation activities and facilities [1].

The general understanding about outdoor recreation applies to physical activity in natural and wilderness areas, but it is now being applied to urban areas [2]. Refer [3] broadly defined outdoor recreation as any leisure time activity conducted outdoors. They categorised outdoor recreation from softsuch as gardening and picnicking to extreme such as para gliding and $4 \mathrm{x} 4 \mathrm{~W}$ off-road driving activities. Depending on the space and place, outdoor recreation can take place almost anywhere and the cost varies.

Though natural resources are important, a destination should not be too dependent on their natural resources only. Creativity and innovation elements are becoming significantly important in today's market because a

Manuscript received October 3, 2013; revised December 1, 2013.

The authors are with the Department of Recreation and Ecotourism, Faculty of Forestry, Universiti Putra Malaysia, Malaysia (e-mail: ssuria4@gmail.com) destination with fewer natural resources can use creativity and innovation to attract more tourists than destinations that have many natural resources. Countries such as Maldives, Singapore and United Arab Emirates are some of the destinations that have limited natural resources but managed to attract influx number of tourists [4]. Conceivably, it is good economics and practice for tourism destinations to have a combination of both creativity and natural resources to expand the market significantly.

This study will examine the role of creativity in enhancing visitors' experience in outdoor recreation activities in a developing country, in this case, Malaysia. This topic is worth looking at due to its novelty and the importance of outdoor recreation activities towards modern healthy lifestyle. Further, because of globalization a visitor destination needs to offer products that are different, globally recognized and yet unique to attract the visitors [5]. Based on that notion this study will discuss mainly findings from the first phase of this study relating to the role of creativity for the outdoor recreation visitors.

\section{NATURE TOURISM DEVELOPMENT}

There is a significant demand for ecological and environmental tourism attraction [5] for more than a decade ago. In this era, nature areas are becoming significantly important for their co logical and social function [6]. Nature tourism activities such as ecotourism and agro tourism have becoming the latest tourism products and niche market in this industry in Europe, outdoor recreation has been the preferred activities to broaden their travel horizons [7]. According [8] found that 26 percent of travelers were engaged in adventure activities on vacation and valued international adventure tourism which mostly involve nature and outdoor activities.

Adventure, as a way of travel, is increasingly appealing to travelers, allowing for a deeper cultural exchange with different people and an appreciation for the fragility of places, and is more often viewed as a "guilt- free" holiday option given that money spent can penetrate more deeply into communities, contributing to local economies [8]. Popular destinations for nature tourism spread almost evenly all over the world compared to other types of tourism activities and attractions where normally developed countries monopolise the market. Hence, Malaysia has substantial potential to tap this market based on their rich natural resources which are suitable for outdoor recreation activities. A report by [9] in National Ecotourism Plan 
Malaysia stated that $14 \%$ to $36 \%$ of tourists in Malaysia participated in ecotourism activities such as sightseeing in the countryside, hiking and trekking.

However, more creativity is needed to make sure these products can compete with other tourism products in the market particularly in developing countries like Malaysia. To date, the products offered to the market by these countries are almost similar making it hard for them to compete with the developed countries [1].

\section{OUTDOOR RECREATION DEVELOPMENT IN MALAYSIA}

The tourism development in Malaysia is growing substantially and almost at par with other developed countries. However, outdoor recreation data from credible sources are lacking and hard to obtain compared to other tourism topics for example marketing and rural tourism. Even with the advancement of technologies today, not much information can be gathered on outdoor recreation in Malaysia.

Malaysian government always gives top priority to tourism agenda due to its important economic contribution to the country for more than two decades. Malaysia is ranked the ninth most visited country by the [10] in 2011, with approximately 24.7 million visitors last year. Malaysia has abundant natural resources [11] which are suitable for recreational activities and should have difficulties in attracting visitors in nature tourism including outdoor recreation. Nevertheless, their market players, policy makers and stakeholders failed to utilize these resources to the fullest. Malaysian tourism players need to be more pro active and think creatively. Creative tourism should be adopted if they want to become competitive and sustain in the tourism market in this era. According to Datuk Ng Yen Yen;

“...attracting more tourists to Malaysia requires industry players to be creative and innovative in providing niche products and services that cater for various markets, including the corporate sector" [12].

The word creative tourism started to appear after the rapid growth of creative industries globally in the late 1990s. Richard and Raymond were among the first scholars to use the term creative tourism in 2000. They define creative tourism as:

...tourism which offers visitors the opportunity to develop their creative potential through active participation in courses and learning experiences which are characteristic of the holiday destination where they are undertaken [13].

Nonetheless, creative tourism is problematic to define due to its multifaceted nature, and facing criticism in the literature due to the newness of this concept. Data is significantly hard to obtain particularly from developing countries such as Malaysia. This topic needs further exploration to get a better understanding.

\section{THE IMPORTANCE OF CREATIVITY}

Today, tourists are demanding and expecting first hand delightful and memorable experiences [14]. Tourism providers need to ensure that they inject some creative elements in order to remain competitive and sustainable [15]. Further, a memorable and quality experience offered to visitors will directly determine a business's ability to generate revenue $g$ [16] particularly for intangible products like outdoor recreation activities. B y adopting creativity either through technologies and modern applications or ideas to their products and services will provide maximum satisfaction to their users or enhance their experience. Outdoor recreation sector in Malaysia where creativity elements is lacking significantly.

\section{VISITORS EXPERIENCE}

According to [16] we have entered into a new economic era where consumers' demand for inherently personal experiences from products or services. They further explained about the relationship between cultural activities such as; outdoor recreation and creative forms of tourism (Table I). The experiences this study is interested to look at is the optimal experience through which they may feel deep involvement, intense concentration, lack of self consciousness and transcendence of a sense of self, all of which lead to an intrinsically rewarding experience [17]. The nature of tourism industry is offering intangible products and services. Due to that, visitors experience play a significant role in sustaining tourism products SXand services in the market as well as attracting potential future repetition. In this ICT era a good combination of modern technology and natural resources such as forest, lakes, mountains, sea, sand and waterfalls can contribute significantly towards users' experience. This is why Disney Land and Disney World theme parks in the US are successful in the world market since the 1950s until now because they used the right formula and mixture of modern technology, ma-made and natural resources in providing a unique and distinct experience to their visitors [16]. Most outdoor recreation destinations in Malaysia offer almost the same activities and programs with several exceptions such as Nomad Adventure, Putrajaya Challenge Park and Botanic Gardens. Without creativity the products and services will be less competitive and lack attractiveness [14]. To date, studies on this present topic is hardly been mentioned in the literature. This study hopes to close the significant gap in the literature.

Refer [14] also notes that many countries have limited heritage attractions to develop or promote, therefore the focus on contemporary, experiential and creative tourism becomes of pivotal importance. According to [13] defines creative tourism as:

“...tourism which offers visitors the opportunity to develop their creative potential through active participation in courses and learning experiences which are characteristic of the holiday destination where they are undertaken"

Although this concept needs in depth research to understand 


\section{Methodology}

Ref. [15] The issues surrounding it, generally policymakers, stakeholders and market players from all sectors agree the significance of creativity and innovation in today's world. Hence, the concept of creative tourism should be adopted by the policy makers and market players in the $\mathrm{t}$ o ur i s m industry particularly in Secondary data from the literature is used for this preliminary report particularly relating to outdoor recreation topics in Kedah, Pahang and Selangor by adopting [15] creative tourism definition. This data will also assist this study to design interview questions and questionnaires in the next stage. In this section the significance role of creativity will be discussed in relation to the development of outdoor recreation activities in the three states.

TABLE I: THE RELATIONSHIP BETWEen CUltural AND CREATIVE Forms OF TOURISM

\begin{tabular}{|l|l|l|l|l|}
\hline & $\begin{array}{l}\text { Primary time } \\
\text { focus }\end{array}$ & Primary cultural focus & $\begin{array}{l}\text { Primary consumption } \\
\text { focus }\end{array}$ & Primary learning focus \\
\hline Cultural tourism & $\begin{array}{l}\text { Past \& } \\
\text { present }\end{array}$ & $\begin{array}{l}\text { High culture, popular } \\
\text { culture }\end{array}$ & Product, process & Passive \\
\hline Creative spectacles & Present & Arts, performance & Performance & Passive \\
\hline Creative spaces & $\begin{array}{l}\text { Present \& } \\
\text { future }\end{array}$ & $\begin{array}{l}\text { Arts, } \\
\text { architecture, design }\end{array}$ & Atmosphere & Interactive \\
\hline $\begin{array}{l}\text { Creative } \\
\text { tourism }\end{array}$ & $\begin{array}{l}\text { Past, present, } \\
\text { future }\end{array}$ & Creative process & $\begin{array}{l}\text { Experience, co-ma } \\
\text { kership }\end{array}$ & Active skill development \\
\hline
\end{tabular}

\section{RESULTS AND DISCUSSION}

Kedah, though the state has many tourism attractions and destinations particularly in nature and eco tourism but Lang kawi Island has out shined the state especially among the international tourists. When t he word "Kedah" was typed using Google scholar engine most of the times the word Langkawi Island pooped up. Most tourists including domestic tourists know the existence of the island more than the state. As a holder of UNESCO geopark status has put Langkawi Island in the world tourism map. Marketing and promotion on other attractions and destinations in Kedah which have potentials for outdoor recreation activities such as Alor Setar, Merdeka beach, mount Jerai and Tanjung Dawai are inadequate and mediocre. Lack of financial and human resources have the main reason for tourism stakeholders in Kedah to be passive with the marketing and promotion either domestically or internationally. Furthermore the activities offered to the visitors are devoid of creativity and innovation. The next phase of this study will look into the possibilities of these under rated places to be developed into functional outdoor recreation areas for the state of Kedah.

Among the limited research undertaken on tourism in rural areas in Kedah (except for Langkawi Island) it is pointed out that there is lack of sensitivity to cater for cultural and ethnic differences in the encounters between the hosts and guests which resulted in constrained meaningful local involvement [18]. Without participation from the hosts tourism activities and development might face with difficulties to expand. While according to [19], the state of Kedah is considered as the economically backward regions together with Perlis and Kelantan with little tourism development. To date creativity elements in outdoor recreation can be experienced and seen mostly in Langkawi Islan only, though most of them are copied from other places.

Pahang, the biggest state in Peninsular Malaysia, has many natural resources suitable for tourism activities particularly for outdoor recreation and some are still not being adequately developed. Pahang has the largest forest reserves, highest peak (Mount Tahan), natural lake (Bera Lake) and national park (Kuala Tahan) in Peninsular Malaysia. Hence, the state has substantial advantages in attracting outdoor recreation users.

The rainforest in Pahang is the oldest in the world, roughly 130 million years old, forest areas cover almost 50 percent of the state [20]. The Malaysian government has gazetted $434359 \mathrm{~km}$ of the rainforest as the country National Park. The popular entrance to the National Park is Kuala Tahan which is located approximately $195 \mathrm{~km}$ (or around two and the half hour's drive) from Kuala Lumpur.

Apart from that, there are many popular tourism destinations located in the state such as Bukit Tinggi, Cherating, Genting Highlands, Kuantan and Tioman Island. This state manages to offer different tourism products such as; the first casino and theme park in the country and elephant sanctuary. These two destinations managed to pull significant number of tourists due to its creativity and uniqueness.

Selangor is the most developed state in Malaysia; it is located next to Kuala Lumpur and Putrajaya making this state competitive and able to attract influx number of international and domestic tourists. Selangor has three major international airports (KLIA, LCCT and Subang Airport) and one port making the state as the most popular post of entrance for international tourists to Malaysia. This state has many developed outdoor recreation destinations such as Bukit Cherakah, Kuala Selangor, Sepang and Shah Alam as well as potential new outdoor recreation destinations that can be further developed.

Selangor is located in the west coast of Peninsular Malaysia. Shah Alam is the capital city of the state which is about $45 \mathrm{~km}$ from Kuala Lumpur and $33 \mathrm{~km}$ from Putrajaya. There are many natural and manmade resources available in Selangor. The state is rich with natural and manmade 
attractions. With its modern tourism facilities and services this state should not be facing any problems in attracting tourists. To date, the state is the richest state in Malaysia in terms of its gross income [21]. Selangor may have many facilities and varieties outdoor recreation products from soft to hard core activities. Nevertheless, the creativity elements reel still lacking and data is hard to obtain particularly in academic literature.

Table II explains the results of selected popular tourism destination in the three states based on the discussion in this section. This study grouped them in three main categories; high level of creativity (HC), middle level of creativity (MC) and low level of creativity (LC) based on the secondary data. The category of $\mathrm{HC}, \mathrm{MC}$ and $\mathrm{LC}$ is identified based on the uniqueness of outdoor recreation activities at these selected destinations based on tourists' activities. The uniqueness activities are measured based on the uncommon outdoor recreation activities and programs according to creative tourism definition by [13], The more uncommon activities and programs at a destination the more unique and creative the destination or programs will be.

TABLE II: Result of CREATIVITy APPLICATION IN SELECTED POPUlAR OUtDOOR RECREATION AREAS IN THREE STATES

\begin{tabular}{|l|l|l|}
\hline Kedah & Pahang & Selangor \\
\hline $\begin{array}{l}\text { KILIM Geopark, } \\
\text { Langkawi } \\
(\boldsymbol{M C})\end{array}$ & $\begin{array}{l}\text { National Park, } \\
\text { Kuala Tahan } \\
(\boldsymbol{M C})\end{array}$ & $\begin{array}{l}\text { I City, } \\
\text { ShahAlam } \\
(\boldsymbol{M C})\end{array}$ \\
\hline $\begin{array}{l}\text { Gunung Mat } \\
\text { Chincang, } \\
\text { Langkawi } \\
(\boldsymbol{M C})\end{array}$ & $\begin{array}{l}\text { Elephant Sanctuary, } \\
\text { Kuala Gandah } \\
(\boldsymbol{M C})\end{array}$ & $\begin{array}{l}\text { Bukit } \\
\text { Cherakah, } \\
\text { Shah Alam } \\
(\boldsymbol{M C})\end{array}$ \\
\hline $\begin{array}{l}\text { Kuah Town, } \\
\text { Langkawi }\end{array}$ & $\begin{array}{c}\text { Cherating } \\
(\boldsymbol{L C})\end{array}$ & $\begin{array}{l}\text { Zoo Negara, Ulu } \\
\text { Klang }\end{array}$ \\
\hline
\end{tabular}

Middle Level of Creativity Low Level of Creativity

From the secondary data gathered by this study one popular destination in Kedah, Pahang and Selangor have low level of creativity? Tourism activities at Kuah Town, Langkawi; Cherating and Zoo Negara, Ulu Klang are common and lacked of uniqueness. While the other two popular destinations at each state have middle level of creativity. This is because KILIM Geopark and Gunung Mat Chincang (Kedah); National Park and Elephant Sanctuary (Pahang); I City and Bukit Cherakah (Selangor) offer some level of uniqueness and uncommon activities to the visitors. From the preliminary study it is found that the stakeholders at these three places failed to include the uniqueness of local communities' culture and lifestyle as one of the tourism attractions, such as the Orang Asli (original/native people) community who are the expert in outdoor activities. Even the places identified as MC are mostly copied their creativity idea from other tourism destinations. However, in depth study will be undertaken in the next stage of this research study to get a more accurate data.

\section{CONCLUSION AND RECOMMENDATIONS}

Although there is a significant interest on outdoor recreation activities by the users today but this topic remain under research in the literature particularly in Malaysia. The highlight for tourists when they engaged in tourism activities is to experience something different from their daily life and that gives unique and enhances their life experience. This is the peak experience and the experiences that are regarded as the extension of the daily experiences to the tourist journey [22], [23]. Local community involvement and participation should be promoted by stakeholders in order to get their support which can contribute maximum experience to the tourists.

The present article describes the initial phase of an extensive research to determine the role of creativity in enhancing visitors experience in outdoor recreation activities in Malaysia. This study aims at generating data on the visitors experience on outdoor recreation activities in Malaysia and how creativity framework can be adopted in products and services provided to be competitive and sustainable in the market.

Both qualitative and quantitative methodology will be employed by this study in a later stage. According to [24], [25] value can be added to a study by the use of a mixed method approach as it can give greater depth and breadth in a local context of an otherwise generic framework.

\section{SUGgestion FOR FURTHER STUdy}

In this globalisation era creativity plays an important aspect in buyer's decision including in the tourism industry. Creativity determines products differentiation and uniqueness of outdoor recreation providers from one another. That is one of the reasons why Disney Land and Disney World theme parks and products survived for many decades until today. Their creativity managed to make them competitive and sustainable in the market when many other theme parks closed down their businesses.

Creativity can also retain customers and making them 
loyal customers. In the stiff competition today, retaining existing customers is more important than finding new customer. Thus, creative promotion is vital for any products particular tourism products due to its intangibility. Promotion should be entertaining and steer away from dull communication messages to capture the market's attention. Creative promotion will help customers to remember certain products and will help small businesses to survive in the market. Through creative promotion will be able to make intangible products to become more tangible. While creative tourism activities will enhance tourists' experience which will create repeat visitation to a destination.

\section{REFERENCES}

[1] C. R. Jensen and S. Guthrie, Outdoor Recreation in America, $6^{\text {th }}$ e d. Human Kinetics: IL, 2006, ch. 1, pp. 9-10.

[2] K. A. Henderson and M. D. Bialeschki, "Leisure and active lifestyles: Research reflections," Leisure Sciences: Interdisciplinary Journal, vol. 27, pp. 355-365, Nov. 2005.

[3] The Queensland Outdoor Recreation Federation. (2012). What is Outdoor Recreation? [Online]. Available: http://www.qorf.org.au/01_cms/details.asp?ID=686.

[4] S. S. Isa and A. Ali, "The development of creative economy in malaysia as experienced in two different case studies," Business, Engineering and Industrial Applications (ISBEIA), pp. 521-526, Nov. 2011.

[5] S. Watson and M. McCracken, "No attraction in strategic thinking: perceptions on current and future skills need for visitors attraction managers," International of Tourism Research, vol. 4, no. 5, pp. 367-378, 2002.

[6] R. W. Coles and S. C. Bussey, "Urban forest landscapes in the UK: Progressing the social agenda," Landscape Urban Plan, vol. 52, pp. 2-3, pp. 181-188, 2000

[7] S. Bell, L. Tyrvainen, T. Sievanen, U. Probstl, and M. Simpson, "Outdoor recreation and nature tourism: A European perspective," Living Reviews in Landscape Research, vol. 1, pp. 1-46, 2007.

[8] Adventure Travel Trade Association, the George Washington University and Vital Wave Consulting. (2012). [Online]. Available: http://www.adventuretravel.biz. 2010.

[9] World Wide Fund for Nature (WWF) Malaysia, "National Ecotourism Plan. Part 3: Ecotourism Guideline for Malaysia," WWF Malaysia, Petaling Jaya. 1996.

[10] The United Nations World Tourism Organization (UNWTO). (2012). [Online]. Available: http://www2.unwto.org/?q=facts/tmt/html.

[11] L. Teh and L. Cabanban, "Planning for Sustainable Tourism in Southern Pulau Banggi: An Assessment of Biophsical Conditions and Their Implications for Future Tourism Development," Journal of Environmental Management, vol. 85, no. 4, pp. 999-1008. 2007.

[12] Be More Innovative and Creative, Industries Players Told. (2010). [Online]. http://www.thestar.com.my/story.aspx?file=\%2f2010\%2f3\%2f22\%2f na tion\%2f5907517\&sec=nation

[13] G. R. Raymonds, "Creative tourism," ATLAS News, vol. 23, pp. 16-20, 2000.

[14] M. K. Smith, "Tourism, Culture and Regeneration," $C A B$ International: Oxfordshire, 2007, ch. 1, pp. 1-11.

[15] G. Richards and J. Wilson, "Developing creativity in tourist experiences: A solution to the serial reproduction of culture?" Tourism Management, vol. 27, no. 6, pp. 1209-1223, 2006

[16] B. J. Pine and J. H. Gilmore, Welcome to the Experience Economy, Harvard Business Review, 1998.

[17] M. Csikszentmihalyi, "Society, Culture, and person: A systems view of creativity," in the Nature of Creativity: Contemporary Psychological Perspectives, R. J. Sternberg, Ed., Cambridge University Press, New York. 1988, pp. 325-339.

[18] A. Liu, "Tourism in rural areas: Kedah, Malaysia," Tourism Management, vol. 27, no. 5, pp. 878-889, 2006.

[19] M. Oppermann, "International Tourism and Regional Development in Malaysia," Journal of Economic and Social Geography, vol. 83, no. 3, pp. 226-233, 1992

[20] Malaysia Timber Council (MTC). (2012). [Online]. Available: http://www.mtc.com.my/info/images/stories/pdf/tm-vol-18-6.pdf.

[21] M. Chew. (2012). Johor to Overtake Selangor as Richest State. [Online]. Available: http://www.mysinchew.com

[22] L. Mossberg, "A Marketing Approach to Tourist Experience," Scandinavian Journal of Hospitality and Tourism, vol. 7, no. 1, pp. 59-74. 2010.

[23] S. Quan and N. Wang, "Towards a structural model of the tourist experience: an illustration from food experiences in tourism," Tourism Management, vol. 25, pp. 297-305, 2004.

[24] S. Berkowitz, "Using qualitative and mixed method approaches," in Needs Assessment: A Creative and Practical Guide for Social Scientist, R. Reviere, S. Berkowitz, C. C. Carter, and C. R. Ferguson, Eds., Taylor and Francis: Washington, 1996, ch. 4.

[25] J. B. Mactavish and S. J. Schleien, "Beyond qualitative and quantitative data linking: an example from a mixed method study of family recreation," Therapeutic Recreation Journal, vol. 34, no. 2, pp. $154-161,2000$

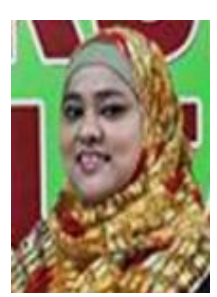

Siti Suriawati Isa was born in Kedah, Malaysia and obtained her early education in Alor Setar, Kedah. She got her Certificate in Travel Operations at Universiti Teknologi Mara (UiTM), Shah Alam, Selongor in 1991. After that she did her Diploma in Tourism Management, UiTM, Shah Alam, Selangor in 1995. She completed her study in B.Sc. (H) In Tourism Management at UiTM, Shah Alam, Selangor in 1997. She did her Graduate Diploma and Master of Tourism at Otago University, Dunedin, New Zealand from 2001 until 2005. Finally she gather P h D from Queensland University of Technology (QUT), Brisbane, Australia in 2012 in Creative Economy. she was appointed as a Senior Lecturer at UPM, Serdang, Selangor, Malaysia in July 2012 until now. She actively involved in research, teaching and community work. Her research interest includes; tourism, recreation, creativity in tourism and hospitality. 